\title{
Upamiętnianie księcia Janusza Starszego a wiedza współczesnego mieszkańca Mazowsza
}

\section{Piotr Piekarz}

\begin{abstract}
STRESZCZENIE
Janusz I Starszy (ok.1346-1429), był jednym z najwybitniejszych książąt mazowieckich, o bardzo dobrej opinii zawartej w Kronice Jana Długosza. Dlatego też władze samorządowe, szukając lokalnej postaci historycznej godnej upamiętnienia, decydują się czasami na księcia Janusza Starszego.

Ważne miejsce upamiętnienia znajduje się w krypcie pod Archikatedrą św. Jana w Warszawie, w postaci sarkofagu z napisem: „Książęta mazowieccy Janusz Starszy, Bolesław III”.

Poza tym Garwolin upamiętnił księcia Janusza, stawiając pomnik. W mieście tym znajduje się także ulica Księcia Janusza, podobnie jak w Ciechanowie, Kolnie, Łomży, Małym Płocku, Przasnyszu, Sochaczewie i Warszawie, a w Ostrołęce - rondo. Władca ten jest również patronem dwóch szkół: w Górze Kalwarii i Łomży, a także Hufca ZHP Warszawa-Centrum. Pewną formą upamiętnienia księcia Janusza Starszego są przedstawienia malarskie, wykonane współcześnie na budynkach w Czersku i Górze Kalwarii. Książę jest także upamiętniany w inscenizacjach historycznych i grach fabularnych.

Biorąc pod uwagę różnorodność upamiętnień, można sądzić, że ta postać historyczna powinna być powszechnie znana. Żeby to sprawdzić w drugiej połowie 2016 roku zostały przeprowadzone badania ankietowe. Objęły one 9 miast, leżących niegdyś w granicach państwa księcia Janusza. Respondentami były osoby pełnoletnie, urodzone i mieszkające na Mazowszu.

Wyniki badań nie są optymistyczne. Spośród 100 respondentów tylko trzech wiedziało o jakiejś formie upamiętnienia tego władcy, a dziewięciu znało tę postać z innych źródeł, związanych w dużej mierze z zamkami, których twórcą lub gospodarzem był właśnie książę Janusz Starszy.
\end{abstract}

\section{Przyczyny upamiętniania księcia Janusza I Starszego}

Janusz I Starszy (ok. 1346-1429) należał do najwybitniejszych władców niezależnego Mazowsza. Z dokumentów jemu współczesnych oraz dzieła Jana Długosza: Roczniki, czyli kroniki sławnego królestwa polskiego, wyłania się dobry gospodarz, dbający o rozwój swojej domeny, czyli księstwa warszawsko-czerskiego. Według krakowskiego kronikarza władca ten, wyróżniający się mądrością i roztropnościa, nazywany był zwierciadłem i wzorem dla innych [Wilska 1986, s. 49; Wilamowski 1999, s. 297]. Ponadto „księstwo swoje pod ów czas płonne i żadnego nie przynoszace pożytku do kwitnacego stanu przyprowadził” [Wilska 1995, s. 12]. Spośród władców Mazowsza wyróżniało go podejmowanie szeregu inwestycji budowlanych [Wilska 1986, s. 24]. Najbardziej spektakularnymi przykładami, zachowanymi w stanie ruiny do dzisiaj, były zamki. Należy także pamiętać o fundowaniu kościołów, wznoszeniu kurii książęcych, strażnic, czy fortyfikowaniu Warszawy. Liczne inwestycje budowlane w połączeniu z dbałością o rozwój osadnictwa, szczególnie w najsłabiej zasiedlonych północnych i wschodnich rejonach księstwa powoduja, że władcę tego porównuje się do Kazimierza Wielkiego, na którego dworze miał dorastać [Wilska 1986, s. 8, 49; Wilska 1995, s. 9]. Następstwem rozwoju osadnictwa było nadanie praw miejskich 24 osiedlom oraz rozbudowa sieci parafialnej [Wilska 1986, s. 8, 49]. 
Książę Janusz I Starszy jest obecnie postrzegany jako postać historyczna, nie dość że wybitna, to jeszcze bez skazy. Wyrazem tego są na przykład słowa ślubowania uczniów rozpoczynających naukę w Gimnazjum nr 8 im. Księcia Janusza I w Łomży: „Książe Januszu I ucz nas rycerskich cnót: odwagi, honoru, wiary, pokory, sprawiedliwości..." [http://pg8.lomza.pl/n, 440html]. Podobne słowa ślubowania równie dobrze mogłyby dotyczyć postaci Zawiszy Czarnego. Nie może dziwić fakt, że lokalne władze chcąc upamiętnić miejscową postać historyczną, decydują się czasami na księcia mazowieckiego Janusza I Starszego. Szczególnie było to widoczne przed zbliżającymi się obchodami 600-lecia bitwy pod Grunwaldem, w której według dzieła Jana Długosza, książę Janusz I Starszy miał osobiście brać udział [Wilska 1986, s. 19]. O tym, że nie każda wyróżniająca się postać historyczna nadawała się do upamiętniania, może świadczyć przykład wybitnego władcy Mazowsza, ojca Janusza I - Siemowita III, na którego cieniem kładzie się tragedia w Rawie Mazowieckiej opisana w Kronice Jana z Czarnkowa. ${ }^{1}$

\section{Sposoby upamiętniania księcia Janusza I Starszego}

Książę Janusz I Starszy mógł być upamiętniony tuż po swojej śmierci wewnątrz kolegiaty św. Jana Chrzciciela, czyli dzisiejszej bazyliki archikatedralnej w Warszawie, w której najpewniej został pochowany pod koniec 1429 r. [Wilska 1986, s. 47]. Formą upamiętniania było niegdyś również nadawanie jego imienia potomkom [Wilska 1986, s. 48], aż do ostatniego męskiego przedstawiciela Piastów mazowieckich, Janusza III, zmarłego w roku 1526.

Przegląd sposobów upamiętniania Janusza Starszego w dzisiejszych czasach rozpoczniemy od miejsca jego pochówku. Przyjmuje się, że został pochowany w obecnej bazylice archikatedralnej św. Jana w Warszawie. Stojąca w tym miejscu drewniana świątynia, była przez księcia Janusza zastąpiona okazalsza, murowaną budowlą która funkcjonowała jako kolegiata [Zagrodzki 2000, s. 6; Celińska 2014, s. 91]. Stając się najważniejszym kościołem na Mazowszu Wschodnim, miał być miejscem pochówku księcia Janusza Starszego i jego rodziny, zgodnie z życzeniem samego władcy, które wyraził w 1412 r. [Wilska 1986, s. 37]. W 1953 r., $\mathrm{w}$ trakcie robót prowadzonych pod prezbiterium tego kościoła, niemal całkowicie zniszczonego pod koniec II wojny światowej, natrafiono na kilka grobów gotyckich. Przyjmuje się, że w jednym z nich mógł być pochowany Janusz Starszy [Zagrodzki 2000, s. 26-27].

Zwiedzając krypty pod bazyliką archikatedralną św. Jana w Warszawie, można dojść w okolice murowanego sarkofagu z napisem: „Książęta mazowieccy Janusz Starszy, Bolesław III" (ryc. 1). W 2009 r. złożono tutaj wieńce z okazji 580. rocznicy śmierci księcia Janusza, po uroczystościach które odbyły się na Zamku Królewskim i w Archikatedrze św. Jana [„Na Szlaku Książąt Mazowieckich” 2010, s. 7].

Okazjami do upamiętniania księcia Janusza Starszego stawały się mniej lub bardziej okrąłe rocznice nadawania przez niego praw miejskich poszczególnym ośrodkom. Czasami po takich obchodach pozostawał materialny ślad. Przykładem może być pomnik księcia Janusza Starszego postawiony w Garwolinie w centrum miasta, na skwerze im. Prezydenta

\footnotetext{
${ }^{1}$ Książę Siemowit III w Rawie Mazowieckiej miał niesłusznie skazać na śmierć za niewierność swoją drugą żonę.
} 


\section{Ryc. 1. Sarkofag księcia Janusza Starszego i Bolesława III w krypcie pod Archikatedrą św. Jana Chrzciciela w Warszawie}

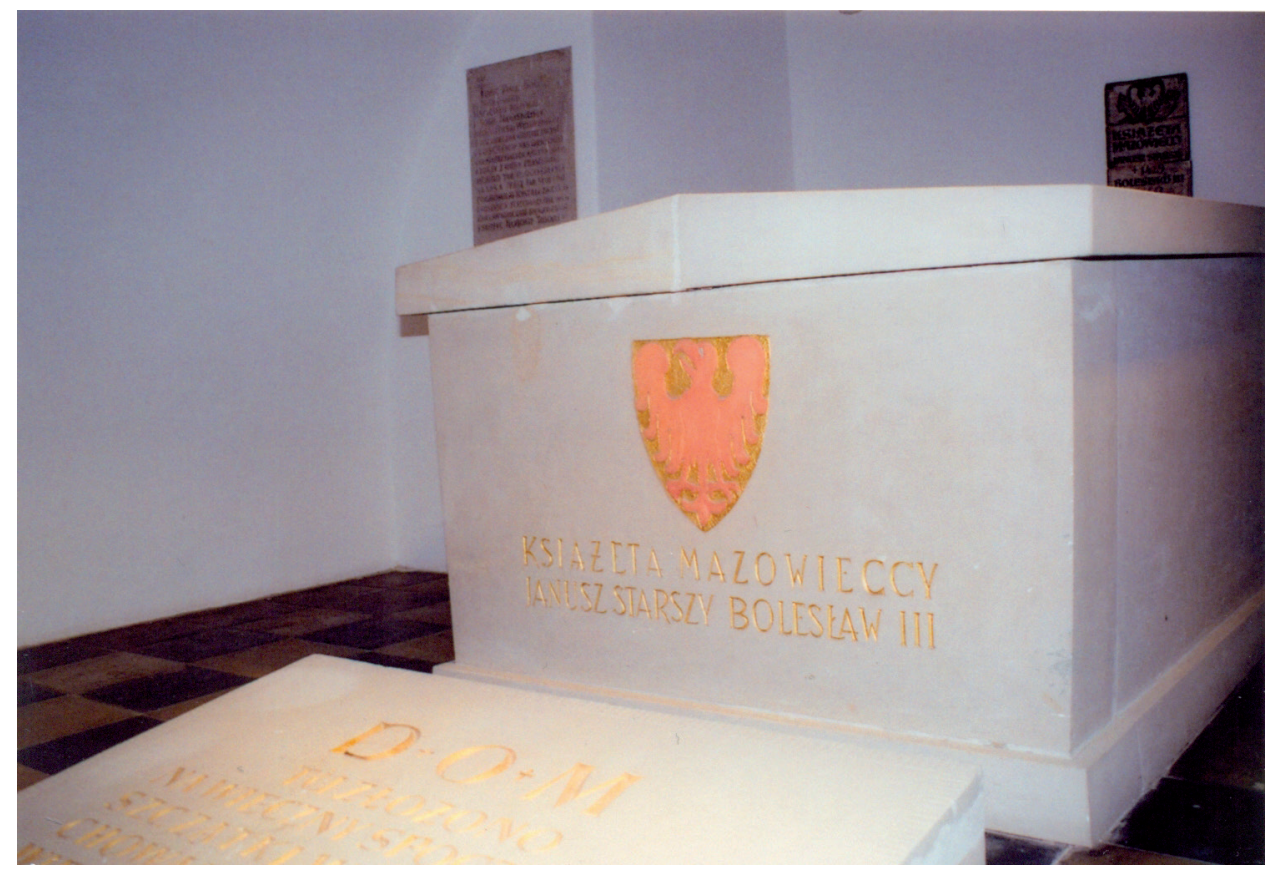

Fot. Piotr Piekarz

Lecha Kaczyńskiego, z okazji przypadającej w 2013 roku, 590. rocznicy nadania przez niego praw miejskich. Pomnik składający się z postaci księcia Janusza, oddalonej od niego dwójki siedzących dzieci i tablic informacyjnych - został zaprojektowany i wzniesiony przez artystę rzeźbiarza Tomasza Górnickiego. ${ }^{2}$ Władca wykonany z brązu, o wysokości około 2 metrów, jest przedstawiony w pozycji stojącej. Prawą rękę ma opartą na rękojeści miecza, a w lewej, wyciągniętej przed siebie, trzyma przywilej lokacyjny (ryc. 2). Drugim przykładem może być Przasnysz, na rynku którego w 1962 r. postawiono obelisk z okazji 3. roku obchodów Tysiąclecia Państwa Polskiego i 535. rocznicy nadania praw miejskich przez księcia Janusza Starszego. ${ }^{3}$ Składał się z 16 płyt, po 4 na każdym boku, zrealizowanych przez artystę rzeźbiarza Edmunda Majkowskiego. Przedstawiały symbolicznie najważniejsze wydarzenia z historii Polski. Jedna ze scen ukazała także Janusza Starszego nadającego prawa miejskie Przasnyszowi, co miało miejsce w roku 1427 [http://www.polskaniezwykla.pl/web/place/ 40199, przasnysz-obelisk-.html; „Na Szlaku Książąt Mazowieckich” 2010, s. 18].

Najpowszechniejszą formą upamiętniania księcia Janusza Starszego było nadawanie ulicom jego imienia. Miało to miejsce w przypadku niektórych miast w województwie

\footnotetext{
${ }^{2}$ Według tablicy informacyjnej przy pomniku.

${ }^{3}$ Według tekstu na obelisku.
} 
Ryc. 2. Pomnik przedstawiający księcia Janusza Starszego w Garwolinie

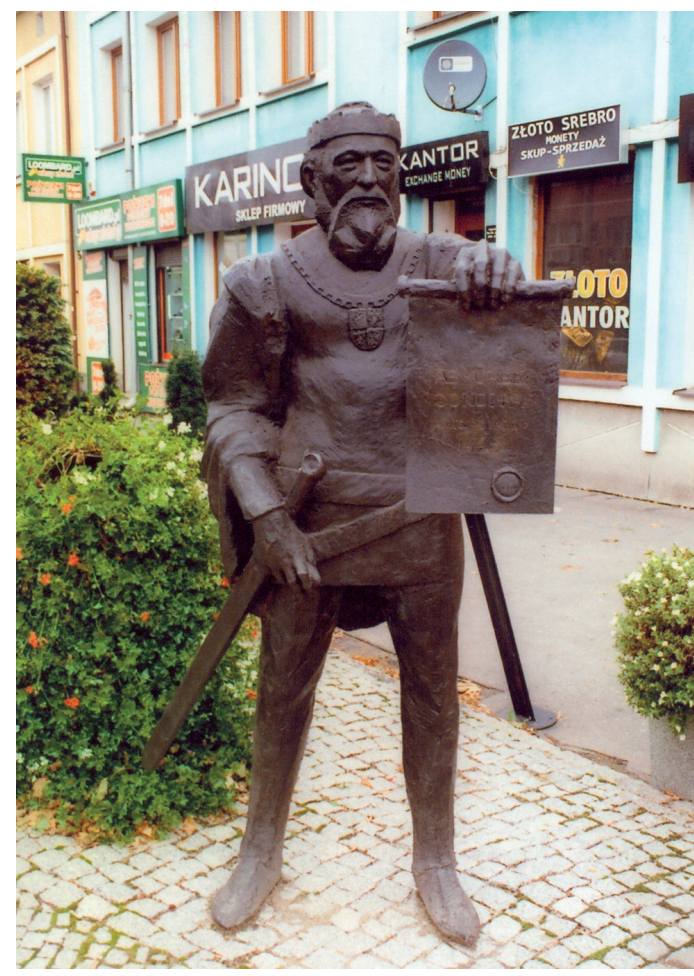

Fot. Piotr Piekarz mazowieckim i podlaskim, leżących niegdyś, poza jednym wyjątkiem, w granicach państwa Janusza Starszego. W większości są to ośrodki, które uzyskały od tego władcy prawa miejskie. Należą do nich: Ciechanów, Garwolin, Kolno, Łomża i Przasnysz. W Garwolinie władca został określony dokładniej jako Janusz I. Podobnie było w przypadku ronda im. Księcia Janusza I, znajdującego się w Ostrołęce, miejscowości, która także uzyskała prawa miejskie od tego władcy. Ulica Księcia Janusza występuje także w Warszawie, ośrodku, którego ranga została poważnie podniesiona w trakcie jego rządów. Wyjątkiem jest tutaj ulica Księcia Janusza w Małym Płocku, tym razem wsi znajdującej się w województwie podlaskim, założonej przez księcia Janusza I w końcu XIV wieku [https://pl.wikipedia.org/ wiki/Mały_Płock]. Miastem, które nie leżało w granicach państwa księcia Janusza, a ma ulicę, której władca ten patronuje, jest Sochaczew. Łączy się ona z ulicą Henryka Sienkiewicza, autora „Krzyżaków”, powieści rozgrywającej się częściowo na dworze tego władcy.

Janusz Starszy stał się patronem dwóch szkół, co stanowiło ważny sposób jego upamiętnienia. Należy do nich Szkoła Podstawowa nr 2 im. Księcia Janusza w Górze Kalwarii (ryc. 3) oraz Publiczne Gimnazjum nr 8 im. Księcia Mazowieckiego Janusza I w Łomży. W tej drugiej placówce, w ramach rozpropagowania wiedzy o patronie, odbyły się konkursy: literacki pod hasłem „Książę Mazowiecki Janusz I - założyciel Łomży” oraz plastyczny - „Portret Księcia Mazowieckiego Janusza I" [http://pg8.lomza.pl/n, 440html].

Janusz I Starszy w 1998 r. stał się również patronem Hufca ZHP Warszawa-Centrum [https://pl.wikipedia.org/wiki/Hufiec_ZHP_Warszawa-Centrum] .

Warszawa oprócz ulicy Księcia Janusza, ma również park imienia tego władcy, położony na Woli, pomiędzy wspomnianą ulicą, a ulicą Obozową.

Do upamiętnień księcia Janusza należą także przedstawienia malarskie. Warto tutaj wspomnieć o trudności w oddaniu rzeczywistego wizerunku władcy, wobec braku dobrych jego wyobrażeń z epoki. Można jedynie wymienić pieczęć pieszą Janusza I, w któ- 
rej książę został ukazany jako stojący rycerz w zbroi [Celińska 2014, s. 89] oraz miniaturę z tak zwanego Kodeksu Świętosławów, datowanego na połowę XV wieku. Wyobrażono tutaj 6 książąt mazowieckich, siedzących wspólnie na niewidocznym siedzisku. Jednym z nich miał być książę Janusz Starszy, ale nie ma pewności co do jego dokładnej identyfikacji [por. Grabowski 2012, s. 513; tamże, ryc. 31]. Nawet gdyby zostało to ustalone, postacie władców zostały ukazane w sposób uproszczony, bez cech portretowych i nie wnoszą żadnych informacji dotyczących ich rzeczywistego wyglądu.

Malarskie przedstawienia księcia Janusza Starszego zostały współcześnie wykonane na zewnętrznych ścianach budynków w Czersku i sąsiadującej z nim - Górze Kalwarii, przez studentów Pracowni Technologii i Technik Malarstwa Ściennego Wydziału Malarstwa Akademii Sztuk Pięknych w Warszawie, w ramach Warsztatów Edukacji Historycznej. W 2006 r. wizerunek księcia Janusza na tle planu pobliskiego zamku książąt mazowieckich, był umiejscowiony w Czersku na ścianie szczytowej budynku Towarzystwa Opieki nad Zabytkami Przeszłości, z okazji 100. rocznicy tej instytucji. (ryc. 4). Rok później malowidło z wyobrażeniem księcia Janusza I pojawiło się na honorowej ścianie Szkoły Podstawowej nr 2 jego imienia w Górze Kalwarii [http://www.gorakalwaria.pl/651-48dbc1e2bdf34-14588-p_1.htm]. Można tutaj dodać obraz przedstawiający Janusza Starszego współczesnej artystki Grażyny Podedwornej, który został przez nią przekazany w darze Publicznemu Gimnazjum nr 8 w Łomży [http://pg8.lomza.pl/n, 440html].

Inny sposób upamiętniania jest związany z utworzonym w ostatnich latach Szlakiem Książąt Mazowieckich. Składa się on z 5 tras, z których jednej patronuje książę Janusz Starszy [http://www.jablonka.com.pl/szlak-ksiazat-mazowieckich]. Szlak jego imienia o długości ponad $300 \mathrm{~km}$ wiedzie na południe od Warszawy przez Czersk, Warkę, Kozienice, Sieciechów, Radom, Iłżę, Szydłowiec, Przybyszew, Grójec, Tarczyn i przez Piaseczno wraca do Warszawy [„Na Szlaku Książąt Mazowieckich” 2012, s. 2]. Na szlaku są rozstawione ta- 


\section{Ryc. 4. Malowidło przedstawiające księcia Janusza Starszego na ścianie szczytowej budynku Towarzystwa Opieki nad Zabytkami Przeszłości w Czersku}

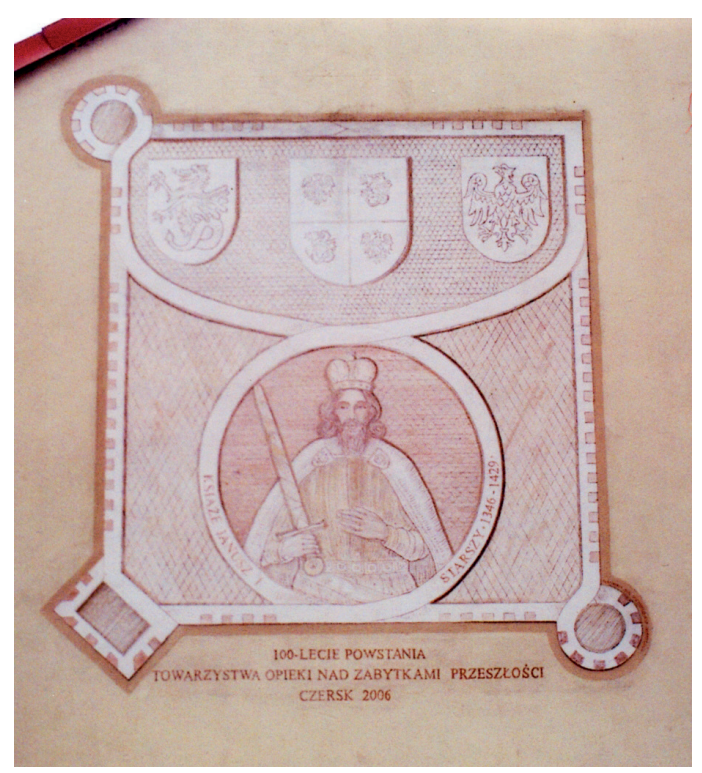

Fot. Piotr Piekarz blice informacyjne współfinansowane przez Europejski Fundusz Rozwoju Regionalnego.

Organizowany był także całodniowy spływ kajakowy - śladami księcia mazowieckiego Janusza I Starszego, który odbywał się najpierw rzeką Pilicą do Wisły, a następnie Wisłą w okolice Czerska [http://www.jablonka.com.pl/szlak-ksiazat-mazowieckich].

Księcia Janusza upamiętniano również poprzez modne w ostatnich czasach działania plenerowe: inscenizacje historyczne, czy też gry fabularne. Spośród ważniejszych inscenizacji historycznych warto wymienić turniej rycerski związany z wymarszem chorągwi księcia Janusza pod Grunwald, który miał miejsce w Górze Kalwarii w maju 2010 r., co wiązało się z uroczystymi obchodami 600-lecia bitwy pod Grunwaldem [,NNa Szlaku Książąt Mazowieckich” 2010, s. 10-11].

Szczególnym wydarzeniem na skalę europejską jest odbywająca się co roku inscenizacja bitwy pod Grunwaldem, w sobotę wypadającą najbliżej daty 15 lipca. Niektórzy członkowie bractw rycerskich występują w trakcie inscenizacji pod chorągwią księcia Janusza Starszego. (ryc. 5). Do tej grupy upamiętnień można także dodać „Spotkanie z historią u księcia Janusza I i księżnej Anny Danuty", które miało miejsce 3 września 2016 r. na zamku w Ciechanowie, w ramach Europejskich Dni Dziedzictwa w połączeniu z Rokiem Henryka Sienkiewicza [http://pomazowszu.pl/ciechanow-spotkania-z-historia-u-ksiecia-janusza-i-ksieznej-annydanuty].

Spośród gier fabularnych związanych z osobą księcia Janusza Starszego można wymienić rycerską grę miejską rozegraną w Ciechanowie 11 sierpnia 2012 r. W jej ramach odbyło się poszukiwanie skarbu księcia Janusza i konkurs na "Giermka księcia Janusza” [„Na Szlaku Książąt Mazowieckich” 2012, s. 7]. Także na zamku w Czersku miała miejsce gra fabularna „Starcie Książąt”, która odbyła się w dniach 13-15 sierpnia 2016 r. Była zapowiadana jako „gra o tron" między księciem Witoldem a jego stryjecznym bratem - Władysławem Jagiełła, mająca się odbyć na dworze szwagra Witolda, czyli księcia mazowieckiego Janusza Starszego [http://pomazowszu.pl/wiadomosciart_w-dniach-13-15-sierpnia-na-zamku-wczersku-odbyło-się-starcie-książąt]. 


\section{Ryc. 5. Narada chorągwi księcia Janusza Starszego przed inscenizacją bitwy pod Grunwaldem Pola Grunwaldu, lipiec, 2003}

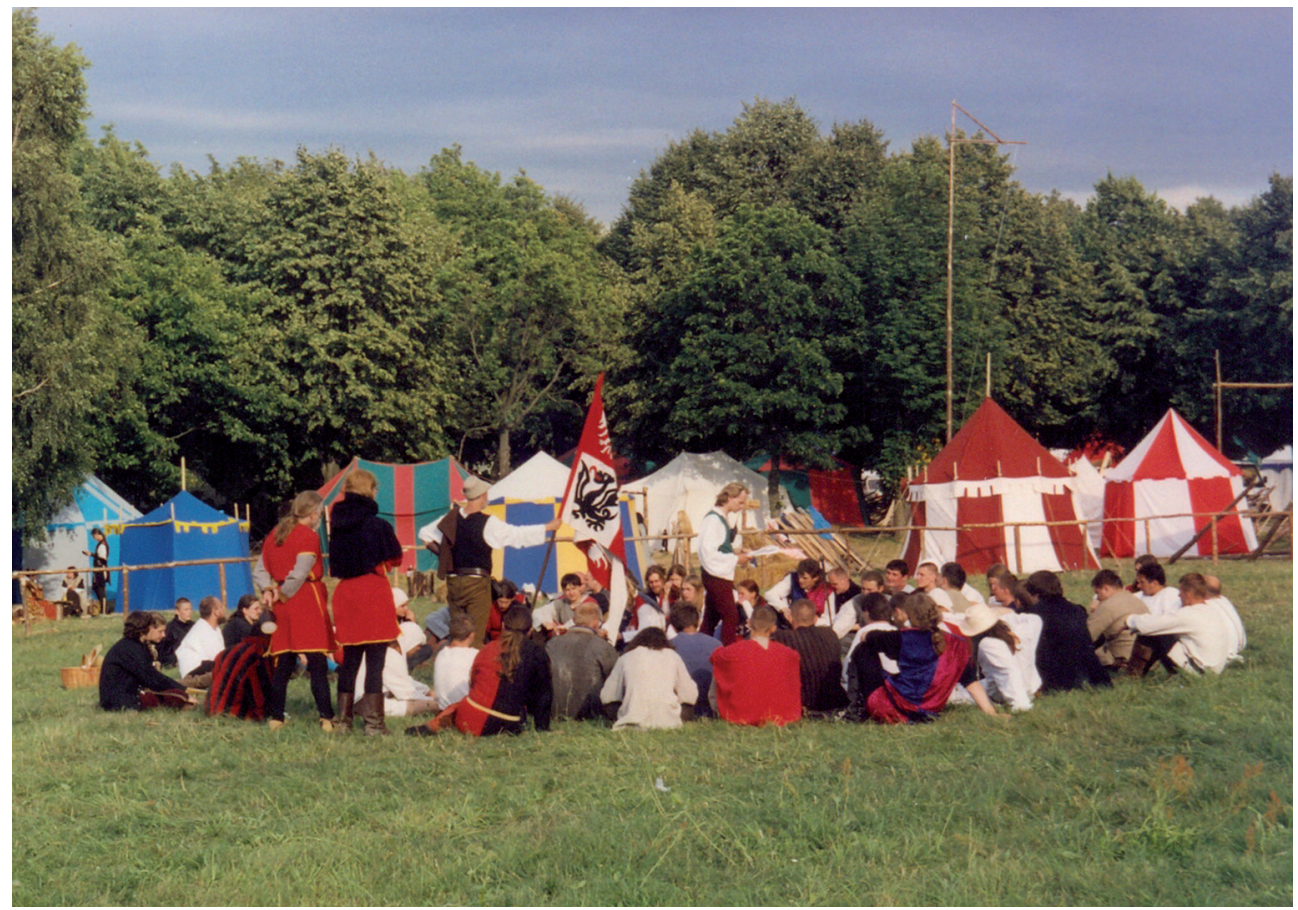

Fot. Piotr Piekarz

W przyszłości Janusz Starszy ma być upamiętniony w Warszawie i Łomży. W stolicy Polski jego imieniem będzie nazwana stacja Metra Warszawskiego (B-6) [https://pl.wikipedia.org/ wiki/ulica_Księcia_Janusza_w_Warszawie].W Łomży natomiast planuje się postawienie jego pomnika [http://www.warszawa,ziemianie.org.pl/artykuly.html].

\section{Przyczyny i cel przeprowadzenia badań ankietowych}

Biorąc pod uwagę wszystkie wymienione wyżej sposoby upamiętnień księcia Janusza, można odnieść wrażenie, że w połączeniu z innymi źródłami informacji, takimi jak, np. literatura, film, ta postać historyczna powinna być dość znana. Jednak niejednokrotnie w rozmowach odnosiłem wrażenie, że taki osąd jest nieprawdziwy. Aby przekonać się, jaki jest rzeczywisty stan wiedzy o tym jednym z najwybitniejszych władców niezależnego Mazowsza, postanowiłem przeprowadzić ankietę w formie ustnej. 
Zasadniczym celem ankiety przeprowadzonej w drugiej połowie 2016 r. było nie tylko ustalenie stanu wiedzy mieszkańców Mazowsza o księciu mazowieckim Januszu Starszym, ale także to, w jakim stopniu upamiętnienia wpłynęły na spopularyzowanie tej postaci historycznej i konkretnie, które najbardziej.

Badania ankietowe zostały przeprowadzone przede wszystkim w części województwa mazowieckiego wchodzącej niegdyś w skład państwa księcia Janusza I, ponieważ na tym terenie skala jego upamiętniania powinna być największa.

Respondentem miała być osoba pełnoletnia, przypadkowo spotkana, która zgodziła się na badanie ankietowe. Jednocześnie musiała urodzić się i mieszkać na Mazowszu, czyli teoretycznie być najbardziej zainteresowana przeszłością obszaru, na którym mieszka. W celu wykluczenia osób pochodzących spoza województwa mazowieckiego, zadawałem pytania wstępne:

1. Czy urodził(a) się Pan(i) na Mazowszu?

2. Czy mieszka Pan(i) na Mazowszu?

Następnie respondentom urodzonym i mieszkającym na Mazowszu, po zaznaczeniu w kwestionariuszu ankiety ich płci (punkt 3.) i przybliżonego wieku z wyglądu (punkt 4.), zadawane były kolejne pytania:

5. Proszę podać nazwę miejscowości, w której Pan(i) mieszka.

6. Proszę podać wykształcenie lub zawód lub rodzaj wykonywanej pracy.

7. Czy słyszał(a) Pan(i) o księciu mazowieckim Januszu Starszym?

8. Jeżeli tak, to proszę podać źródło informacji i jakieś fakty z życia tego władcy.

Druga część ostatniego pytania nie była zadawana respondentom, którzy słyszeli o jakimś rodzaju upamiętniania księcia Janusza, albo sami brali udział w jego upamiętnieniu.

\section{Wyniki przeprowadzonej ankiety}

Spośród 100 respondentów urodzonych i mieszkających na Mazowszu, z którymi udało się przeprowadzić ankiety, jeden z respondentów brał udział w upamiętnianiu księcia Janusza Starszego, dwóch respondentów słyszało o jakiejś formie jego upamiętniania, a kolejnych dziewięciu respondentów wiedziało o nim z innych źródeł. Sumując, spośród 100 respondentów, 12 cokolwiek wiedziało o księciu mazowieckim Januszu Starszym.

$\mathrm{Z}$ wyjątkiem Warszawy, ankiety były przeprowadzane maksymalnie z dziesięcioma mieszkańcami danej miejscowości. Łącznie badania zostały wykonane w dziewięciu miastach, takich jak: Ciechanów, Góra Kalwaria, Grójec, Mińsk Mazowiecki, Piaseczno, Warka, Warszawa, Wyszogród i Zakroczym. Czasami zdarzało się, że ankiety przeprowadzono z respondentami przyjezdnymi, pochodzącymi z innych miejscowości na Mazowszu, w których takie badania się nie odbyły. Reprezentowali oni następujące miejscowości: Grodzisk Mazowiecki, Kołbiel, Prace Duże, Pułtusk, Stanisławów, Treblinkę i Wólkę Kozłowską.

Warto tutaj zaznaczyć, że ankiety były przeprowadzane tylko w miejscowościach, które miały coś wspólnego z księciem Januszem Starszym. Grójec, tak jak i Ciechanów, Mińsk Mazowiecki, Piasecznoi Wyszogród, otrzymały od tego władcy prawa miejskie. W Ciechanowie ponadto znajdowała się jego rezydencja. W Górze Kalwarii były przeprowadzone ankiety ze 
Ryc. 6. Mapa z zaznaczeniem miejscowości, w których były prowadzone badania ankietowe (czerwony prostokąt) oraz miejscowości będących miejscami zamieszkania respondentów, pochodzących spoza miast, w których wykonywano ankiety (biały prostokąt z czerwoną obwódką). Pierwsza liczba w nawiasie wskazuje liczbę respondentów mieszkających w danej miejscowości, druga - liczbę respondentów danej miejscowości, którzy coś wiedzieli o księciu Januszu Starszym

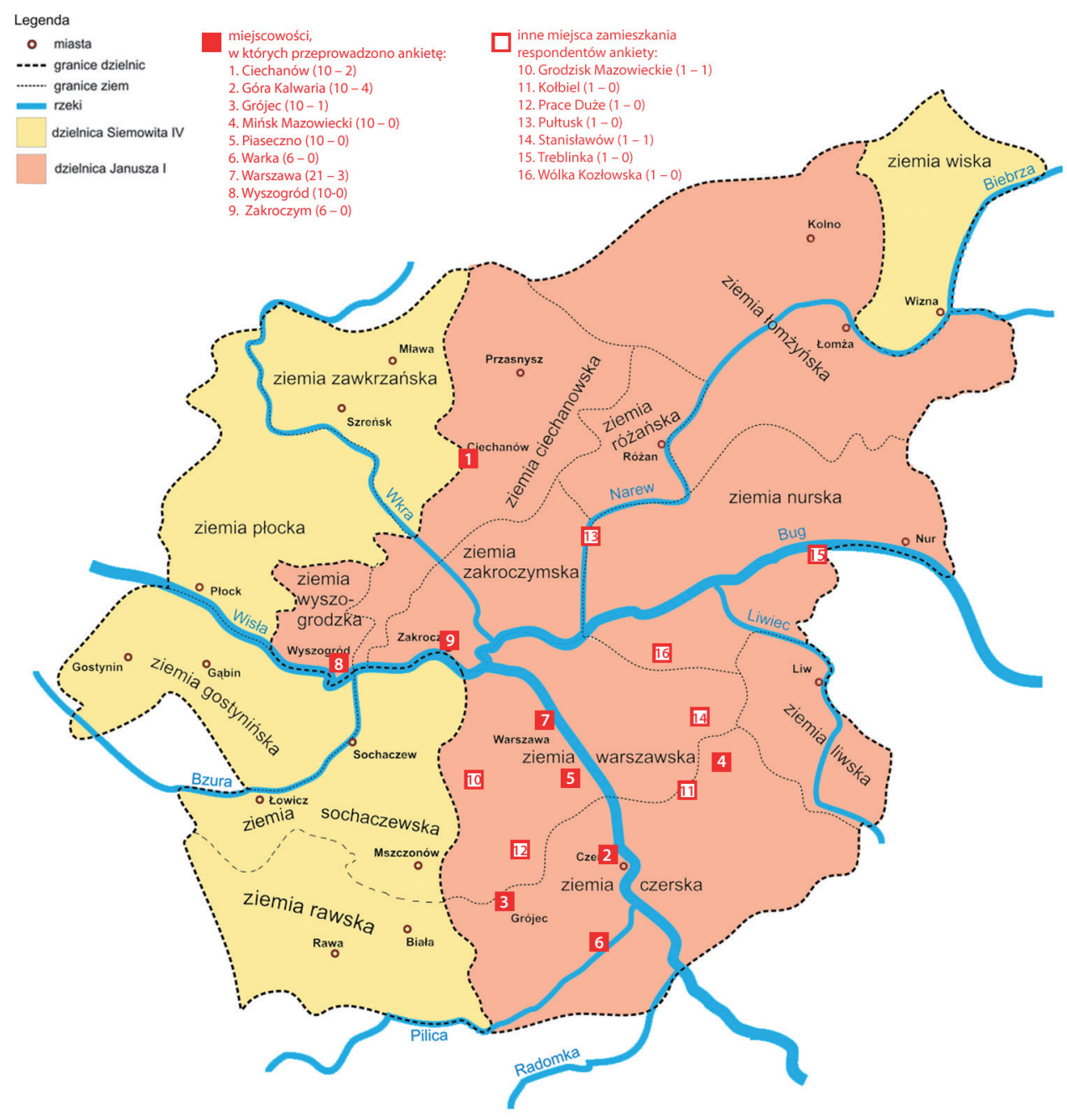

Źródło: tło - By Fjl - licencja: CC BY-SA 3.0, (https://commons.wikimedia.org/w/index.php?curid=206035 http:// www.pl.wikipedia.org/wiki/Mazowsze); oznaczenia miejscowości, w których przeprowadzono ankietę - Piotr Piekarz 
względu na bliskość Czerska - obecnie wsi, a niegdyś zamku - rezydencji księcia Janusza i osiedla, któremu książę Janusz nadał prawa miejskie. W Warszawie, dlatego, że ośrodek ten za rządów księcia Janusza Starszego, został podniesiony do rangi głównego ośrodka księstwa, pełniącego rolę stolicy [Wilska 1986, s. 49]. W Warce natomiast władca ten odnowił i rozszerzył przywileje miejskie [Wilska 1995, s. 9-10]. Ponadto w tutejszym kościele p.w. Matki Boskiej Szkaplerznej według tradycji znajduje się pochówek księżnej Anny Danuty, małżonki księcia Janusza Starszego [http://www.jablonka.com.pl/szlak-ksiazat-mazowieckich]. Zakroczym był natomiast miejscem, w którym odbywały się wiece i zjazdy książąt mazowieckich. Tutaj, wzorem swojego ojca Siemowita III, książę Janusz Starszy ogłosił statuty dla ziemi mazowieckiej [Wilska 1986, s. 30]. W miejscu tym książę miał także jedną ze swoich siedzib o charakterze mieszkalno-administracyjno-gospodarczym, czyli kurię książęcą [Celińska 2014, s. 91].

Z badań ankietowych wynika, że najwięcej osób słyszało o księciu Januszu Starszym w Górze Kalwarii, graniczącej z Czerskiem, w której na 10 respondentów, aż 4 odpowiedziało pozytywnie. Na kolejnych miejscach jest Ciechanów, gdzie na 10 respondentów, 2 odpowiedziało pozytywnie oraz Warszawa, w której na 21 respondentów, 3 odpowiedziało pozytywnie. Trzeba tutaj pamiętać, że Warszawa, Czersk i Ciechanów, należały do najważniejszych miejscowości w okresie rządów księcia Janusza Starszego. Poza tym 1 respondent na 10, odpowiedział pozytywnie w Grójcu. Dodać tutaj trzeba jeszcze po 1 respondencie ze Stanisławowa i Grodziska Mazowieckiego, którzy także słyszeli o księciu Januszu Starszym, ale pochodzili z miejscowości, w których ankiety nie były przeprowadzane. W miejscowościach takich jak: Mińsk Mazowiecki, Piaseczno i Wyszogród, na 10 przeprowadzonych ankiet, nikt nie słyszał o księciu Januszu Starszym. Natomiast w Warce i Zakroczymiu na 6 przeprowadzonych ankiet, nikt nie słyszał o tym władcy, tak samo jak po 1 respondencie z Kołbieli, Prac Dużych, Pułtuska, Treblinki i Wólki Kozłowskiej, czyli w miejscowościach, w których badania ankietowe nie były przeprowadzane (ryc. 6).

Jak już zostało wspomniane wyżej, 3 respondentów albo było związanych z upamiętnieniem albo słyszało o jakimś rodzaju upamiętnienia księcia Janusza Starszego. Respondentem, który upamiętniał tego władcę, był mężczyzna w wieku ok. 30-40 lat, zamieszkały w Warszawie, będący filmowcem i nauczycielem języka angielskiego, związany z bractwem rycerskim, pasjonat średniowiecza. Poza nim, mimo przeprowadzenia badań w takich miejscowościach, jak Ciechanów, czy Góra Kalwaria koło Czerska, w których lub w pobliżu których co jakiś czas odbywają się inscenizacje lub gry historyczne powiązane z osobą księcia Janusza Starszego, żaden respondent o takim rodzaju jego upamiętnienia nie słyszał.

Jeden respondent słyszał o ulicy Księcia Janusza w Warszawie (ryc. 7). Była to kobieta, w wieku ok. 60-70 lat, zamieszkała w Warszawie, pracująca jako geolog. W tym przypadku można łatwo wytłumaczyć znajomość ulicy Księcia Janusza zlokalizowanej na Woli, ponieważ znajduje się tam Instytut Geofizyki Polskiej Akademii Nauk [https://pl.wikipedia.org/ wiki/ ulica_Księcia_Janusza_w_Warszawie]. Nikt z respondentów nie wspominał o ulicy Księcia Janusza Starszego zarówno w Ciechanowie, jak i Warce, gdzie takie ulice się znajdują.

W przypadku upamiętnień księcia Janusza w postaci nazw ulic jest pewien problem. Wśród nich są bowiem ulice niewielkie, występujące na obrzeżach miast, tak jak w Ciechanowie 
i Kolnie. W Garwolinie znajduje się większa ulica wylotowa, ale także na obrzeżach miejscowości. Inne są małymi uliczkami w lepszej lokalizacji, jak na przykład w Przasnyszu, Sochaczewie i Warce. Do tej grupy można dodać rondo Księcia Janusza I w Ostrołęce. W przypadku Łomży i Warszawy, są to ulice drugorzędne, a jedynie we wsi Mały Płock, ulica Księcia Janusza należy do główniejszych i sięgających do centrum. Istnieje jeszcze jeden problem. Poza ulicą w Garwolinie i rondem w Ostrołęce, gdzie na tabliczkach widnieje napis: Księcia Janusza I, w większości miejsc ograniczono się do napisu: ulica Księcia Janusza, mimo, że w dynastii książąt mazowieckich, było trzech władców o tym imieniu. Poza tym w przypadku Ciechanowa, tabliczka zawiera napis ulica Ks. Janusza, co równie dobrze mogłoby dotyczyć jakiegoś księdza Janusza (ryc. 8). Najgorzej wygląda sytuacja w Warce, ponieważ tam nazwa ulicy Księcia Janusza występuje tylko na mapie, a nie w terenie, na Osiedlu Książąt Mazowieckich. Jedna z osób mieszkających na tym osiedlu od ponad 20 lat, zapytana wprost o tę ulicę, zupełnie o niej nie wiedziała.

Jeden respondent wspomniał o szkole podstawowej im. Księcia Janusza w Górze Kalwarii. Była to kobieta w wieku ok. 40-50 lat, mieszkanka Góry Kalwarii, będąca księgową. W przypadku Łomży, gdzie znajduje się Publiczne Gimnazjum nr 8 im. Księcia Mazowieckiego Janusza I, badania ankietowe nie były prowadzone.

Pozostałych 9 respondentów miało wiedzę o księciu Januszu Starszym z innych źródeł niż upamiętnienia.

Trzech respondentów dowiedziało się o tym władcy z książek lub broszur, dotyczących dziejów miasta i okolic, w których sami mieszkali. Jeden z nich, to mężczyzna z Grójca w wieku ok. 50-60 lat, będący geodetą. Z książek dotyczących historii Grójca pamiętał, że Janusz Starszy nadał temu ośrodkowi prawa miejskie. Dwaj pozostali respondenci, to mężczyźni mieszkający w Górze Kalwarii. Obaj byli z wyglądu w podobnym wieku ok. 60-70 lat. Jeden z nich,

\section{Ryc. 7. Tabliczka z nazwą ulicy Księcia Janusza w Warszawie na Woli}

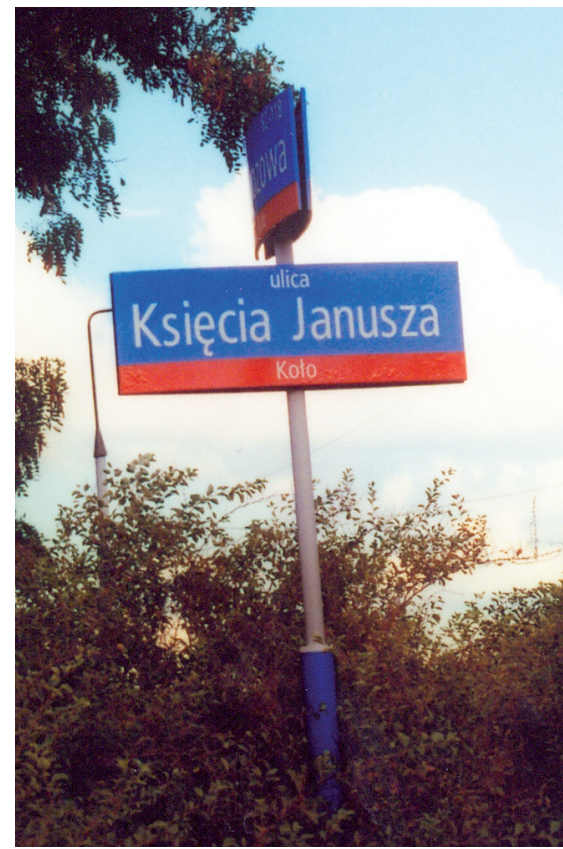

Fot. Piotr Piekarz

\section{Ryc. 8. Tabliczka z nazwą ulicy Ks. Janusza w Ciechanowie}

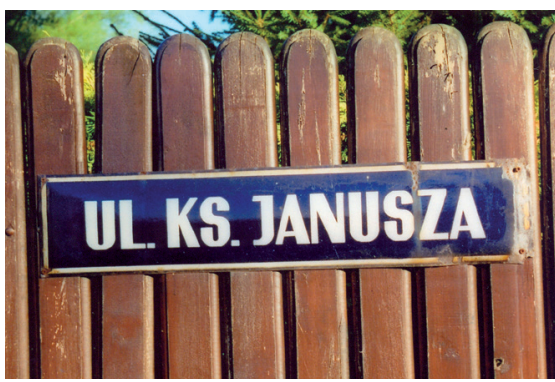

Fot. Piotr Piekarz 
elektryk, z książeczki/broszury, którą w latach 50. minionego wieku miał napisać nauczyciel miejscowej szkoły podstawowej, wiedział, że zamek w Czersku był siedzibą księcia Janusza Starszego. Także drugi mężczyzna, fryzjer, z broszury o Górze Kalwarii pozyskał informację, że Janusz Starszy rezydował w Czersku.

Dwóch respondentów kojarzyło księcia Janusza Starszego z filmu fabularnego „Krzyżacy” w reżyserii Aleksandra Forda, wyprodukowanego w roku 1960, czyli dokładnie na 550. rocznicę bitwy pod Grunwaldem. Należy on do najsłynniejszych polskich filmów. Szacuje się, że został obejrzany przez ponad 32 miliony widzów [„Na Szlaku Książąt Mazowieckich 2010, s. 9; „Metro” 2015, s. 6]. W rolę księcia Janusza Starszego wcielił się tutaj Tadeusz Białoszczyński. W 1970 r. nakręcono w Polsce jeszcze jeden film, którego akcja toczyła się na dworze tego władcy w Ciechanowie. Była to produkcja przygodowa dla młodzieży pt. „Pierścień Księżnej Anny” w reżyserii Marii Kaniewskiej. W porównaniu z filmem „Krzyżacy”, jest on dzisiaj mało znany. Na przykład na filmwebie, najpopularniejszym polskim internetowym serwisie filmowym, do dnia 8 stycznia 2017 r., film „Krzyżacy” został oceniony przez 39931 widzów, a 1758 osób wyraziło chęć jego obejrzenia, tymczasem film „Pierścień Księżnej Anny”, został oceniony przez 428 widzów, a 120 osób wyraziło chęć jego obejrzenia. W drugim filmie rolę księcia Janusza zagrał Andrzej Szalawski, pamiętny Jurand ze Spychowa z filmu „Krzyżacy”. Respondentami, którzy kojarzyli księcia Janusza Starszego z filmem „Krzyżacy” byli: mężczyzna z Warszawy, w wieku ok. 60-70 lat, będący stolarzem oraz mężczyzna ze Stanisławowa, w wieku: ok. 30-40 lat, będący rolnikiem.

Jeden respondent przeczytał o księciu Januszu w internecie. Była to kobieta z Góry Kalwarii, w wieku ok. 60-70 lat, po szkole medycznej. Poszukując w internecie informacji o zamku w Czersku, osoba ta dowiedziała się przy okazji o związku tego zamku z księciem Januszem Starszym. W internecie znajdują się nie tylko podstawowe, ale również bardziej szczegółowe informacje dotyczące tego władcy zawarte na przykład na takich portalach, jak: Wikipedia Wolna Encyklopedia, www.szkolnictwo.pl, www.poczet.com, czy szlakksiazat.pl.

Kolejny respondent słyszał o księciu Januszu z tablicy informacyjnej postawionej na wolnym powietrzu. Pochodził on z Grodziska Mazowieckiego, a więc z miejscowości, w której nie były prowadzone badania. Ankieta została przeprowadzona w Wyszogrodzie. Mężczyzna w wieku ok. 50-60 lat, będący konstruktorem maszyn, dowiedział się z tablicy informacyjnej, że książę Janusz Starszy nadał prawa miejskie Wyszogrodowi. O tym wydarzeniu informowała tablica nr 5 z cyklu: „Zabytki Wyszogrodu”, która dotyczyła konkretnie Starego Rynku. Oprócz tych tablic, znajdowały się także tablice z serii: „Szlak Książąt Mazowieckich", informujące między innymi o Górze zamkowej i wzniesionym na niej zamku za czasów księcia Siemowita III lub jego syna Janusza I. Dzięki funduszom unijnym Mazowiecka Regionalna Organizacja Turystyczna, poczynając od czerwca 2011 r., mogła postawić ponad 130 tablic oznakowujących Szlak Książąt Mazowieckich oraz ponad 100 tablic opisujących zabytki i miejscowości leżące na szlakach [„NNa Szlaku Książąt Mazowieckich" 2010, okładka]. Spośród miejscowości, w których były przeprowadzone ankiety, takie tablice istniały w: Ciechanowie, Piasecznie, Warce, Wyszogrodzie i Zakroczymiu. 
Niektórzy respondenci mówili, że dowiedzieli się o księciu Januszu w trakcie nauki szkolnej. Ponieważ jednak nic bliższego nie potrafili powiedzieć o tym władcy, taka odpowiedź nie była uznawana. Wyjątkiem jest mężczyzna z Ciechanowa, w wieku ok. 60-70 lat, będący rolnikiem, który pamiętał ze szkoły o powiązaniach księcia Janusza Starszego z zamkiem w Ciechanowie.

Drugim respondentem z Ciechanowa, posiadającym wiedzę o księciu Januszu Starszym, był mężczyzna w wieku ok. 30-40 lat, pracujący jako pomoc w opiece społecznej. Dowiedział się o księciu Januszu Starszym na wystawie znajdującej się na zamku w Ciechanowie, zatytułowanej: „Księstwo Mazowieckie 1200-1526: intrygi, trucizny i smok, czyli 300 lat niezależnego Mazowsza". Wystawa ta zawierająca elementy multimedialne, została otwarta pod koniec 2014 r. [http://szlakksiazat.pl/o-szlaku-ksiazat-mazowieckich]. Jest określana, jako pierwsza w Polsce wystawa, kompleksowo poświęcona dziejom niezależnego Mazowsza i najważniejszym wydarzeniom, które je ukształtowały. ${ }^{4}$ Ekspozycja jest zaaranżowana w licznych, niewielkich pomieszczeniach znajdujących się w zamkowych basztach. Przewodnik opowiada o kolejnych władcach Mazowsza i jednocześnie, o zmianach zachodzących w wyglądzie samego zamku. W jednym z pomieszczeń książę Janusz Starszy wraz z małżonką księżną Anną Danutą „zapraszali na ucztę". Znajdują się tutaj także zdjęcia z filmu „Krzyżacy” oraz miejsce, gdzie na kartce zawierającej życiorys księcia Janusza Starszego, można sobie przybić pieczęć, wykonaną na wzór pieczęci tego władcy.

Postać księcia Janusza Starszego jest przybliżona także na ekspozycji stałej, znajdującej się w Muzeum im. Kazimierza Pułaskiego w Warce, zatytułowanej: „Warka - miasto dotknięte historią”.

\section{Wnioski końcowe}

Badania ankietowe przeprowadzone wśród 100 respondentów, wykazały, że 12 z nich wiedziało coś o księciu mazowieckim Januszu Starszym, z czego 3 respondentów słyszało o nim z różnych sposobów upamiętniania. Można zadać pytanie, czy 100 respondentów, jest wystarczającą liczbą do uznania ich za reprezentacyjną grupę, zróżnicowaną wiekowo i pod względem wykształcenia, by stwierdzić, że 12\% mieszkańców Mazowsza, leżącego niegdyś w granicach państwa księcia Janusza Starszego, o nim słyszało, z czego 3\% miało wiedzę o jakiś sposobach jego upamiętnienia. Centrum Badania Opinii Społecznej prowadzi na przykład badania na reprezentacyjnej, ok. 1000 osobowej próbie dorosłych mieszkańców [http://www.cbos.pl/PL/home/home.php]. Ośrodek Badania Opinii Publicznej nieraz przeprowadzał ponad 1300 ankiet [http://www.tnsglobal.pl/coslychac/2016/12/16/8-mld-zl-na-wyjazdy-swiateczne/\#more-2556]. Jednak powyższe przykłady dotyczą badań ogólnopolskich, a analizowane tutaj badania dotyczą przede wszystkim Mazowsza historycznego, pozostającego w granicach obecnego województwa mazowieckiego.

Żeby wykazać, że zwiększenie liczby respondentów nie będzie miało wpływu na poważniejszą zmianę wyniku przeprowadzonych badań, przedstawiam tabelę 1., która wykazuje procentowy udział respondentów wiedzących coś o księciu Januszu Starszym, w stosunku do całkowitej liczby respondentów.

\footnotetext{
${ }^{4}$ Por. ulotki wydane przez Muzeum Szlachty Mazowieckiej w Ciechanowie.
} 
Tabela 1. Procentowy udział respondentów wiedzących coś o księciu Januszu Starszym, w stosunku do całkowitej liczby respondentów

\begin{tabular}{|c|c|c|}
\hline Liczba respondentów & Liczba odpowiedzi pozytywnych & Procent odpowiedzi pozytywnych \\
\hline 10 & 2 & 20,0 \\
\hline 20 & 2 & 10,0 \\
\hline 30 & 3 & 10,0 \\
\hline 40 & 4 & 10,0 \\
\hline 50 & 4 & 8,0 \\
\hline 60 & 6 & 10,0 \\
\hline 70 & 7 & 10,0 \\
\hline 80 & 8 & 10,0 \\
\hline 90 & 11 & 12,2 \\
\hline 100 & 12 & 12,0 \\
\hline
\end{tabular}

Z ankiety wynika, że mniej więcej co 10. respondent coś wiedział o księciu Januszu Starszym. Można sądzić, że jest to dobry wynik, mając na względzie, że w dynastii Piastów mazowieckich, było trzech władców o tym samym imieniu: Janusz I Starszy, Janusz II i Janusz III. Mogły więc zdarzać się pomyłki i w kilku przypadkach, faktycznie się zdarzyły. Kilku respondentów pomyliło Janusza Starszego z Konradem Mazowieckim twierdząc, że sprowadził on Krzyżaków na ziemie polskie. Jedynie w dwóch przypadkach pomyłka dotyczyła księcia Janusza III. Jeden respondent zastanawiał się, czy Stanisławów nie otrzymał praw miejskich z rąk księcia Janusza Starszego, chociaż faktycznie miejscowość ta otrzymała prawa miejskie od dwóch ostatnich książąt mazowieckich - Stanisława i Janusza III. Inny respondent uważał, że Janusz Starszy, wraz ze swoim bratem, jako ostatni książęta mazowieccy, zostali pochowani w bazylice katedralnej św. Jana w Warszawie, zamiast księcia Janusza III.

Badania ankietowe pokazuja że wiedza o księciu Januszu Starszym wynika w dużej mierze z istnienia zamków, budowli, które władca ten wznosił lub rozbudowywał. Obecnie ich ruiny, bardzo atrakcyjne wizualnie są wykorzystywane jako muzea, sceneria dla przedsięwzięć plenerowych: turniejów rycerskich, czy gier historycznych. Spośród 12 respondentów posiadających jakąś wiedzę o księciu Januszu Starszym, 6 wiedziało o nim w kontekście zamków w Czersku i Ciechanowie. Czytali o tym w publikacjach (2 respondentów) lub internecie (1 respondent). Dowiedzieli się o tym zwiedzając muzeum zamkowe (1 respondent) albo z nauki szkolnej (1 respondent). Jeden, będąc członkiem bractwa rycerskiego związanego z zamkiem, brał udział w działaniach upamiętniających tego władcę. Reasumując, gdyby nie zamki, wiedza o księciu Januszu Starszym byłaby znacznie słabsza. 
Jeżeli chodzi o upamiętnienia, to dotychczasowe działania, mające za cel wzbudzanie i utrwalanie pamięci o tej postaci historycznej, nie za bardzo spełniają swoją funkcję, ponieważ tylko 3 respondentów na 100, wiedziało o księciu Januszu Starszym z jakiejś formy jego upamiętnienia. Przykładem może być Warszawa, która dużo księciu Januszowi zawdzięcza, a przytaczając słowa z serwisu internetowego oddziału warszawskiego Polskiego Towarzystwa Ziemiańskiego:„(...) Warszawa, jak dotychczas, upamiętnita postać księcia nazwaniem Jego imieniem matej uliczki na Woli. Czy to wystarczy? Czy ksiażę swoją dziatalnościa dla Warszawy nie zasłużył sobie na bardziej godne upamiętnienie..."[http://www.warszawa. ziemianie.org.pl/artykuly.html: (W sprawie pomnika Janusza I; red. 13.10.2013.)]

Jest jednak iskierka nadziei na zmianę. W przyszłości ma w Warszawie powstać stacja metra nazwana imieniem księcia Janusza (B-6), a wiadomo, że tym środkiem komunikacji porusza się duża liczba mieszkańców. Jeżeli na stacji metra w widocznym miejscu pojawi się informacja przybliżająca postać tego władcy, na przykład razem ze zdjęciami z filmu „Krzyżacy", to na pewno dla wielu osób świadomość istnienia takiej postaci historycznej, stanie się sporym odkryciem.

\section{Bibliografia}

Celińska U., 2014, Działalność gospodarcza i kulturalna książąt mazowieckich Janusza I Starszego oraz Siemowita IV, „Saeculum Christianum”, 21, s. 81-92.

Grabowski J., 2012, Dynastia Piastów Mazowieckich. Studia nad dziejami politycznymi Mazowsza, intytulacja i genealogia książat, Wydawnictwo Avalon, Kraków.

Janko z Czarnkowa, Kronika, http://biblioteka.kijowski.pl/sredniowiecze/janko\%20z\%20 czarnkowa\%20-\%20kronika.pdf

„Metro", (Film dnia), środa: 2.09.2015., s. 6.

„Na Szlaku Książąt Mazowieckich”, 2010, 1, 4, marzec-kwiecień.

„Na Szlaku Książąt Mazowieckich”, 2012, 1, 10, wrzesień-październik.

Wilamowski M., 1999, Janusz I Starszy, [w:] S. Szczur i K. Ożóg (red.), Piastowie. Leksykon Biograficzny, Wydawnictwo Literackie, Kraków, s. 294-297.

Wilska M., 1986, Ksiażę Janusz Starszy, Zamek Królewski w Warszawie, Warszawa.

Wilska M., 1995, Dwaj bracia - Janusz I Starszy i Siemowit IV, „Mazowsze”, 6, 2, s. 7-12.

Zagrodzki T., 2000, Gotycka architektura katedry św. Jana w Warszawie, DiG, Warszawa.

\section{Źródła internetowe}

http://pg8.lomza.pl/n,440html [dostęp dnia: 11.10.2016].

http://pomazowszu.pl/ciechanow-spotkania-z-historia-u-ksiecia-janusza-i-ksieznej-annydanuty [dostęp dnia: 19.10.2016]. 
http://pomazowszu.pl/wiadomosciart_w-dniach-13-15-sierpnia-na-zamku-w-czerskuodbyło-się-starcie-książąt [dostęp dnia: 19.10.2016].

http://szlakksiazat.pl/o-szlaku-ksiazat-mazowieckich [dostęp dnia: 19.10.2016].

http://www.cbos.pl/PL/home/home.php [dostęp dnia: 24.01.2017].

http://www.gorakalwaria.pl/651-48dbc1e2bdf34-14588-p_1.htm [dostęp dnia: 11.10.2016].

http://www.jablonka.com.pl/szlak-ksiazat-mazowieckich [dostęp dnia: 11.10.2016].

http://www.polskaniezwykla.pl/web/place/40199,przasnysz-obelisk-.html [dostęp dnia: 24.01.2017].

http://www.tnsglobal.pl/coslychac/2016/12/16/8-mld-zl-na-wyjazdy-swiateczne/\#more-2556 [dostęp dnia: 24.01.2017].

http://www.warszawa,ziemianie.org.pl/artykuly.html [dostęp dnia: 19.10.2016].

https://pl.wikipedia.org/wiki/Hufiec_ZHP_Warszawa-Centrum [dostęp dnia: 24.01.2017].

https://pl.wikipedia.org/wiki/Mały_Płock [dostęp dnia: 19.10.2016].

https://pl.wikipedia.org/wiki/Mazowsze [dostęp dnia: 19.10.2017].

https://pl.wikipedia.org/wiki/ulica_Księcia_Janusza_w_Warszawie [dostęp dnia: 11.10.2016].

\section{The commemoration of the Duke Janusz Starszy and the knowledge of the contemporary inhabitant of Mazovia}

\section{ABSTRACT}

Janusz I the Old (about 1346-1429), is one of the most distinguished dukes of Mazovia. He has a very good opinion in the Chronicle of Jan Długosz. This is the main reason, why local authorities decide on Duke Janusz I the Old, when they are looking for a local, historical figure for commemoration.

The crypt of St. John's Archicathedral in Warsaw is important place of commemoration. There is a sarcophagus with the inscription: Dukes of Mazovia Janusz I the Old (and) Bolesław III. Garwolin also commemorated him. There is Janusz I the Old Monument. Besides that, in the town has been located Janusz I the Old Street, as in the other towns: Ciechanów, Kolno, Łomża, Mały Płock, Przasnysz, Sochaczew and Warsaw. Ostrołęka has Janusz I the Old Round about. Two schools: in Góra Kalwaria and Łomża, as well as Warsaw Centrum District of Polish Scauting and Guiding Association, have used the name of Duke Janusz I the Old. A certain form of commemoration are modern paintings representing Duke Janusz I the Old. They have been made on the walls of buildings in Czersk and Góra Kalwaria. The Duke is also commemorated in historical re-enactment and role-playing games.

Taking into consideration the diversity of commemorations, it can be assumed that this historical figure should be widely known. Questionnaire surveys have been conducted during the second half of 2016 years, in order to verify this knowledge. For the research purpose were selected 9 cities, which had been located within the borders of Duke Janusz I the Old state. The respondents were only adults, born and currently living in Mazovia. The results of the research are not optimistic. Among the 100 respondents, only three of them knew something about commemoration of Duke Janusz I the Old. Nine respondents knew about the Duke from other sources mostly associated with the castles, built or rebuilt by Janusz I the Old.

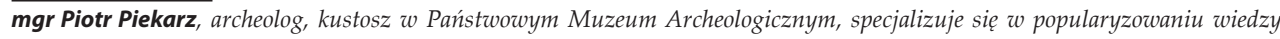
archeologicznej i historycznej / archaeologist, a curator at the State Archaeological Museum in Warsaw, specializes in the popularization of archaeological and historical knowledge. 